\title{
Trombositopeninin nadir bir sebebi: Leptospirozis
}

\section{A rare cause of thrombocytopenia: Leptospirosis}

\author{
Fatma Aybala Altay ${ }^{1}$, Murat Albayrak ${ }^{2}$, Gönül Çiçek Şentürk ${ }^{1}$, Harika Çelebi², Esra Sarıbacak Can², \\ İrfan Şencan ${ }^{1}$
}

1 Dışkapı Yıldırım Beyazıt Search and Training Hospital, Infectious Diseases and Clinical Microbiology Department, İrfan Baştuğ Caddesi, Dışkapı, Ankara, Turkey

2 Dışkapı Yıldırım Beyazıt Search and Training Hospital, Hematology Department, İrfan Baştuğ Caddesi, Dışkapı, Ankara, Turkey

Sir,

Referral of the patients coming with fever and thrombocytopenia to hematology clinics is a usual situation. Final diagnose may be a viral infection and sometimes infections of some rare microorganisms. Leptospirosis should be taken into account in our country, Turkey. We present such a patient who admitted to hematology policlinic with fever and thrombocytopenia, was diagnosed as leptospirosis and completely healed with appropriate treatment.

\section{Case}

Twenty two years old male patient suffering from fever, fatique and pain of scruff and eyes applied to hematology policlinic. His complaints had begun suddenly 5-6 days ago, fever had raised up to 40 degrees at first three days and begun declining for two days. His initially performed tests at his locale resulted as: WBC:5300/ $\mu \mathrm{L}, \mathrm{Hb}: 13.1 \mathrm{~g} / \mathrm{dL}$, Platelets: $22000 / \mu \mathrm{L}$, Total bilirubine:1.6, Direct bilirubine: $0.8 \mathrm{mg} / \mathrm{dL}$, ALT: 47 U/L, AST: 52 U/L, ALP: 113 U/L, LDH: 215U/L,

Key words: fever; leptospirosis; thrombocytopenia

Anahtar kelimeler: ateş, leptospiroz, trombositopeni 
CK: 487U/L, GGT: $60 \mathrm{U} / \mathrm{L}$. Whole abdominal CT was normal. He was conscious, his general situation was moderate - poor, there was no pathological findings at his physical examination. His blood count and serum biochemical analysis were as follows: WBC: $7600 / \mu \mathrm{L}, \mathrm{Hb}: 14.4 \mathrm{~g} / \mathrm{dL}$,

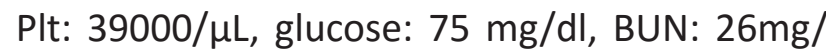
dl, creatinine: $0.67 \mathrm{mg} / \mathrm{dl}$, AST:31 U/L, ALT:55 $\mathrm{U} / \mathrm{L}$, Total bilirubine: $0.9 \mathrm{mg} / \mathrm{dl}$, Direct bilirubine: $0.4 \mathrm{mg} / \mathrm{dl}, \mathrm{ALP}: 124 \mathrm{U} / \mathrm{L}, \mathrm{GGT}: 77 \mathrm{U} / \mathrm{L}, \mathrm{CK}: 68$ U/L, LDH:250 U/L. Direct, indirect and Coombs and complemented Coombs tests were negative. Microscopic hematuria was determined at his urinanalys. There was no atypical cells at his peripheral blood smear but 2-3 single platelets were seen at every fields. His urine and blood samples were taken for culture and serological tests of TORCH, viral hepatitis, Sandfly Fever, Chrimmean Congo Hemoragic Fever, Hantavirus infection, Brucellosis and Leptospirosis. Sulbactam ampicillin and ciprofloxasin were given empirically. From the second day of treatment his general situation and laboratory findings improved obviously. Leptospira MAT (microagglutination) test resulted as: positive for Leptospira icterohaemorrhageae at $1 / 800$ titer. The patient was discharged by healing and complete normalisation of hemogram and biochemical tests after 9 day treatment of sulbactam ampicillin.

\section{Discussion}

Viral infections and some zoonoses should be also taken into account as well as hematologic pathologies for the patients having fever and thrombocytopenia. Especially his location, job, contact with rodents etc... should be investigated for the exposure because such epidemiological data may lead to diagnosis. Leptospirosis is one of the mostly seen zoonoses. It is caused by pathogenic spirochetes from the genus Leptospira (1). Direct or indirect contact with infected animals or their urines at urban areas is the main route of transmission (2). Our patient's job was cleaning of irrigation canals of farmlands that is coherent with this route.

The disease is observed as anicteric mild, self limiting form at approximately $90 \%$ of the patients and as serious potentially fatal form characterised by any combinations of renal failure, liver failure and pneumonitis with hemorrhagic diateses at the others (1). It's a two phase disease as leptospiremia phase and immunological phase for each of the forms and these phases usually cannot be seperated from each other (1). Thrombocytopenia is the most common hematological manifestation in severe forms of leptospirosis and it's generally correlated with poor outcomes (3-5). Leptospira microscopic agglutination test(MAT) is the most used diagnostic tool for suspected patients. Titer of $\geq 1 / 200$ is suggestive enough when clinical findings are present. Titer of $1 / 800$ or 4 fold increase of titer after 10 days interval is evident for the diagnosis (1).

Antibiotics and supporting treatments should be used for the patients immediately. If the disease is not treated appropriately within the first 2-3 days, it may progress in severity (6). So, initial suspect about the disease in differential diagnose is very important. It should be remembered especially for the patients having fever, orbital pain, thrombocytopenia, mild elevations at transaminases with elevations at creatin cinase and bilirubines and/or impairment of kidney function tests. Early diagnose and treatment can avoid transition to immunologic phase and reduce the mortality (6). 


\section{REFERENCES}

1. Levett PN, Haake DA. Leptospirosis In: Mandell GL, Bennett JE, Dolin R(Eds). Principles and Practice of Infectious Disease Newyork: Churchill Livingstone; Vol 2, 2010: 3059-65.

2. Levett PN. Leptospirosis. Clin Microbiol Rev. 2001;14:296-326.

3. Bharti AR, Nally JE, Ricaldi JN, Matthias MA, Diaz MM, Lovett MA, et al. Peru-United States Leptospirosis consortium. Leptospirosis: a zoonotic disease of global importance. Lancet Infect Dis. 2003;3:757-71.
4. Edwards CN, Nicholson GD, Everard COR. Thrombocytopenia in leptospirosis. American Journal of Tropical Medicine and Hygiene 1982;31(4):827-9.

5. Turgut $M$, Sünbül $M$, Bayirli D, Bilge A, Leblebicioğlu $H$, Haznedaroğlu I. Thrombocytopenia complicating the clinical course of leptospiral infection. J Int Med Res 2002;30 (5):535-40.

6. Kobayashi_Y. Human leptospirosis: management and prognosis. J Postgrad Med 2005;_51(3):201-4. 